\title{
ע Kouluterveydenhoitajan palvelut: sosiodemografisten tekijöiden yhteys nuorten kokemuksiin
}

Sosiodemografisten tekijöiden on todettu olevan yhteydessä nuorten palvelujen saatavuuteen ja kokemuksiin palveluista. Tutkimuksen tarkoituksena oli kuvata sukupuolen, kouluasteen, sosioekomisen aseman, kuntaryhmityksen ja syntyperän yhteyttä nuorten kokemaan tyydyttymättömään palvelutarpeeseen kouluterveydenhoitajan palvelujen näkökulmasta. Tutkimuksessa käytettiin valtakunnallisen Kouluterveyskyselyn aineistoa vuodelta $2017(n=139829)$. Aineistosta rajattiin pois ne nuoret, joilla ei ollut ollut tarvetta kouluterveydenhoitajan palveluille. Rajausten jälkeen aineistoksi muodostui 28967 8.- ja 9.-luokkalaisen sekä lukioiden ja ammatillisten oppilaitosten I. ja 2. vuoden opiskelijan vastaukset.

Nuorten palvelutarpeen tyydyttymistä tutkittiin palvelujen käyttöä sekä tuen ja avun saamista koskevilla kysymyksillä. Analyysia varten muodostettiin 4-luokkainen yhdistelmämuuttuja, jonka luokat olivat I) päässyt palveluihin ja saanut tukea, 2) päässyt palveluihin mutta ei saanut tukea, 3) ei päässyt palveluihin mutta saanut tukea sekä 4) ei päässyt palveluihin eikä saanut tukea. Aineistoa analysoitiin ristiintaulukoinnilla, $\chi 2$-testillä ja multinomiaalisella regressioanalyysilla.

Yksitoista prosenttia nuorista oli kokenut tyydyttymätöntä palvelutarvetta kouluterveydenhoitajan palveluissa. Kaikilla tutkittavilla taustatekijoillä havaittiin tilastollisesti merkitsevä yhteys nuoren kokemaan tyydyttymättömään palvelutarpeeseen. Erityisesti nousi esiin perheen huonon taloudellisen tilanteen sekä nuoren ulkomaalaistaustaisuuden yhteys koettuun tyydyttymättömään palvelutarpeeseen. Suomalaiset nuoret eivät ole yhdenvertaisessa asemassa kouluterveydenhoitajan palvelujen saatavuudessa eikä tuen ja avun saamisessa.

ASIASANAT: nuoret, opiskeluhuolto, palvelujen saatavuus, tyydyttymätön palvelutarve

LAURA VÄLKKILÄ, KATJA JORONEN, ANNA-MAIJA KOIVISTO, OUTI KANSTE

\section{YDINASIAT}

- Nuorten taustatekijöillä tiedetään olevan yhteys koettuun tyydyttymättömään palvelutarpeeseen

- Tutkimuksen tuloksissa nousi esiin erityisesti perheen huonon taloudellisen tilanteen ja nuoren ulkomaalaistaustaisuuden yhteys koettuun tyydyttymättömään palvelutarpeeseen kouluterveydenhoitajien palvelujen osalta
- Tyydyttymättömään palvelutarpeeseen yhteydessä olevien tekijöiden tunnistamisella voidaan kehittää nuorten palvelujärjestelmää toimivammaksi 


\section{JOHDANTO}

Suomessa oli vuoden 2017 loppuun mennessä yhteensä noin 295000 iältään 14-18-vuotiasta lasta ja nuorta (1). Näistä lapsista ja nuorista valtaosa voi hyvin sekä kansallisen että kansainvälisen arvioinnin mukaan (2). Kuitenkin pieni osa lapsista ja nuorista voi todella huonosti $(2,3)$. Ongelmana on pahoinvoinnin ja vähäosaisuuden polarisoituminen osalle lapsista ja nuorista, mikä voi lisätä heikompiosaisten syrjäytymisen ja pahoinvoinnin riskiä $(4,5)$. Koulu- ja työelämän ulkopuolelle jäämisen eli niin sanotun NEET-statuksen on todettu olevan yhteydessä terveydellisiin ja taloudellisiin riskeihin (6,7). Suomalaisista 15-29-vuotiaista nuorista ja nuorista aikuisista joka kahdeksas $(13 \%)$ - OECD-maiden keskiarvon ollessa myös $13 \%$ - on pudonnut koulu- ja työelämän ulkopuolelle (8). Nuorempien 15-19-vuotiaiden ikäryhmässä NEET-nuoria on Suomessa vain neljä prosenttia, OECD-maiden keskiarvon ollessa kuusi prosenttia (9). Onkin tärkeä tutkia suomalaisia nuoria siinä vaiheessa, kun he vielä ovat kiinnittyneitä kouluun.

Suomen sosiaali- ja terveyspolitiikan strategisena tavoitteena on yhteiskunta, jossa väestöä kohdellaan yhdenvertaisesti, kaikilla on mahdollisuus osallisuuteen sekä jokaisen ihmisen terveyttä ja hyvinvointia edistetään (10). Koululla ja opiskeluhuollolla on universaalina palveluna hyvät mahdollisuudet kehittää ja tukea lasten ja nuorten hyvinvointia (11). Vuonna 2014 voimaan astuneen oppilas- ja opiskelijahuoltolain tarkoituksena on edistää muun muassa opiskelijoiden hyvinvointia ja osallisuutta (12). Lain tullessa voimaan otettiin käyttöön käsite opiskeluhuolto, jolla viitataan sekä oppilas- että opiskelijahuoltoon. Opiskeluhuoltopalvelut sisältävät kouluterveydenhoitajan palvelujen lisäksi koululääkärin, kuraattorin ja psykologin palvelut (13.) Opiskeluhuollon henkilöstö on avainasemassa ongelmien varhaisessa tunnistamisessa ja tuen tarjoamisessa $(14,15)$.

Opiskeluhuollon palvelujen saatavuus on parantunut joitain poikkeuksia lukuun ottamatta (12), mutta oppilaitosten ja alueiden välillä on edelleen eroja palvelujen saatavuudessa (11, 13,16,17). Vuoden 2014-2015 tietoihin perustuvan tutkimuksen mukaan suosituksen mukainen terveydenhoitajamitoitus saavutettiin 61 prosentissa kouluista (13). Tuoreen kansallisen tutkimustiedon mukaan noin joka kymmenes koulu- terveydenhoitajalta tukea ja apua tarvitseva nuori jäi vaille tukea ja apua (18). Opiskeluhuollon palvelujen saavutettavuudessa on havaittavissa aluekohtaista vaihtelua $(13,16,19,20)$. Vuosina 2016-2018 toteutetun Lapsi- ja perhepalvelujen muutosohjelman tavoitteena oli lapsi- ja perhepalvelujen uudistaminen siten, että ne vastaisivat aiempaa paremmin lasten, nuorten ja perheiden tarpeisiin (21). Muutosohjelmassa vahvistettiin peruspalveluja sekä ehkäisevien palvelujen ja varhaisen tuen asemaa (22). Uudistuksen myötä tavoitellaan palveluihin muutoksia, joiden avulla saataisiin edistettyä palvelujen asiakaslähtöisyyttä, yhdenvertaisuutta ja kattavuutta (23).

Nuorille tarjottavien palvelujen lähtökohtana tulisi olla palvelujen helppo saavutettavuus, jota voidaan arvioida muun muassa palvelujen sijainnin, saatavuuden sekä maksullisuuden näkökulmista $(17,24)$. Nykyisessä palvelujärjestelmässä nuorten mahdollisuudet käyttää palveluja eivät kuitenkaan aina ole yhdenvertaiset $(13,17$, 20,24). Palvelujen saatavuutta arvioidaan usein palvelujen käytöllä. Palvelujen saatavuuden arviointi palvelujen käytön perusteella ei ole kuitenkaan aukoton, sillä käytölle voi olla esteitä, jotka vaikeuttavat palvelujen saatavuuden arviointia käytön perusteella (25.) Esteet palvelujen käytölle voivat liittyä palvelujen käyttäjään $(25,26,27)$ tai palvelurakenteeseen, kuten palvelun hintaan tai sijaintiin $(25,27)$. Palvelujen saatavuutta voidaan arvioida tarkastelemalla tyydyttymätöntä palvelutarvetta palvelujen käytön sijaan, jolloin arvioitu palvelutarve suhteutetaan toteutuneeseen palvelujen käyttöön (25). Tässä tutkimuksessa nuoren kokemalla tyydyttymättömällä palvelutarpeella tarkoitetaan nuoren kokemusta siitä, että nuori ei ole saanut tarvitsemaansa tukea ja apua kouluterveydenhoitajalta. Tässä tutkimuksessa keskitytään tarkastelemaan palvelutarpeen tyydyttymistä kouluterveydenhoitajan palvelujen näkökulmasta, sillä kouluterveydenhoitajaa voidaan pitää asetuksen antamiin henkilöstömitoituksiin perustuen nuoren helpoiten tavoitettavissa olevana opiskeluhuollon ammattilaisena (13).

Lasten ja nuorten hyvinvointia käsittelevissä tutkimuksissa on keskitytty aiemmin pääasiassa terveys-, hyvinvointi- ja osaamisnäkökulmiin, joten avun saamiseen tai palvelujen tarpeisiin vastaamiseen liittyvää tietoa on saatavilla vain vähän (28). Tiedetään, että lasten ja nuorten palvelujen 
saatavuuteen ja kokemuksiin palveluista vaikuttavat sosioekonomiset ja -demografiset tekijät $(29,30)$. Kirjallisuuskatsauksen mukaan lasten ja nuorten palvelujen saatavuuteen ja kokemuksiin palveluista vaikuttavat merkittävästi muun muassa nuoren asuinalue, sukupuoli, etnisyys, vammaisuus, seksuaali- ja sukupuoli-identiteetti sekä kumuloituva vähäosaisuus ja sosioekonominen asema (29). Katsauksen heikkoutena voidaan pitää sitä, että vain osassa katsauksen tutkimuksia tarkasteltiin sosioekonomisia tekijöitä. Tämä tutkimus vastaakin tärkeään tutkimustarpeeseen nuorten tyydyttymättömästä palvelutarpeesta suomalaisessa koulukontekstissa. Tyydyttymätöntä palvelutarvetta käsittelevässä aiemmassa tutkimuksessa on tunnistettu sekä sosioekonomisilla että -demografisilla tekijöillä kuten taloudellisella tilanteella (25) sekä huonolla terveydentilalla olevan yhteys tyydyttymättömän palvelutarpeen kokemiseen $(25,31)$. Vastaavasti nuoruudessa koetun tyydyttymättömän palvelutarpeen on tunnistettu olevan yhteydessä aikuisiän huonoon terveydentilaan (32).

Sukupuolen yhteys koettuun tyydyttymättömään palvelutarpeeseen vaihtelee eri tutkimusten mukaan, sillä osassa on havaittu eroa sukupuolten kokemassa tyydyttymättömän palvelutarpeen esiintyvyydessä $(18,30,33,34)$, mutta osassa ei ole havaittu sukupuolten välillä olevan suurta eroa tyydyttymättömän palvelutarpeen kokemisessa (25).

Nuoriin kohdistuvissa tutkimuksissa on tarkasteltu vain harvoin palvelujen tarpeisiin vastaamista tai koettua tuen ja avun saamista. Tämän tutkimuksen tavoitteena on tuottaa uutta, kansallista tutkimustietoa taustatekijöiden yhteydestä nuorten kokemuksiin palvelujen saatavuudesta sekä tuen ja avun saamisesta. Tutkimuksen tuottama tieto lisää palvelujärjestelmätutkimuksen tietopohjaa ja sen avulla voidaan kehittää opiskeluhuollon palveluja vastaamaan paremmin nuorten tarpeita.

Tutkimuksen tarkoituksena on kuvata taustatekijöiden yhteyttä nuorten kokemaan tyydyttymättömään palvelutarpeeseen kouluterveydenhoitajan palveluista. Taustamuuttujina olivat sukupuoli, kouluaste, sosioekonominen asema, kuntaryhmitys ja syntyperä.

\section{TUTKIMUKSEN AINEISTO JA MUUTTUJAT}

Kouluterveyskysely on joka toinen vuosi toteutettava kokonaistutkimus, joka kerää tietoa muun muassa lasten ja nuorten hyvinvoinnista, terveydestä, opiskelusta, avun saamisesta sekä palvelujen vastaavuudesta tarpeisiin (35). Terveyden ja hyvinvoinnin laitoksen tutkimuseettinen työryhmä on arvioinut Kouluterveyskyselyn (36). Tutkimus toteutettiin Tutkimuseettisen neuvottelukunnan hyvän tieteellisen käytännön periaatteiden mukaisesti (37). Kouluterveyskyselyn aineisto on kerätty nuorilta anonyymisti koulupäivän aikana ja siihen vastaaminen on ollut vapaaehtoista (38).

Tutkimuksessa käytettiin valtakunnallisen Kouluterveyskyselyn aineistoa vuodelta 2017 ( $\mathrm{n}=139$ 829). Tässä tutkimuksessa kiinnostuksen kohteena olivat nuoret, jotka ilmaisivat tyydyttymätöntä palvelutarvetta kouluterveydenhoitajan palveluista. Nuorten palvelutarpeen tyydyttymistä tutkittiin palvelujen käyttöä sekä tuen ja avun saamista koskevien kysymysten avulla. Molemmissa kysymyksissä valittiin mukaan vain ne vastaukset, jotka koskivat kouluterveydenhoitajan palveluja.

Palvelujen käyttöä kysyttiin kysymyksellä: "Oletko käynyt tämän lukuvuoden aikana koulusi terveydenhoitajan, lääkärin, kuraattorin tai psykologin luona (muuten kuin terveystarkastuksessa)"? Vastausvaihtoehdot olivat 1) en, ei ole ollut tarvetta, 2) en, yritin enkä päässyt, 3) kyllä, 1-2 kertaa, 4) kyllä, 3-5 kertaa, 5) kyllä, yli 5 kertaa. Aineistosta rajattiin pois ne vastaajat, jotka eivät olleet kokeneet tarvetta palvelujen käyttämiselle eli vastausvaihtoehdon 1 (en, ei ole ollut tarvetta) valinneet nuoret.

Koettua tuen ja avun saamista tutkittiin kysymyksellä "Oletko saanut tukea ja apua hyvinvointiisi seuraavilta koulun aikuisilta tämän lukuvuoden aikana"? Vastausvaihtoehdot olivat 1) kyllä, paljon, 2) kyllä, jonkin verran, 3) en, mutta olisin tarvinnut ja 4) en ole tarvinnut apua. Myös tästä kysymyksestä rajattiin pois ne nuoret, jotka olivat vastanneet tähän kysymykseen vaihtoehdon 4 (en ole tarvinnut apua). Näiden rajausten jälkeen aineisto muodostui 28967 nuoren vastauksesta. Palvelutarpeen tyydyttymisestä muodostettiin 4-luokkainen yhdistelmämuuttuja edellä kuvattujen muuttujien avulla. Muuttujan muodostaminen on kuvattu taulukossa 1. 
Taulukko 1. Palvelutarpeen tyydyttymistä kuvaavan 4-luokkaisen yhdistelmämuuttujan muodostaminen

\begin{tabular}{|c|c|c|}
\hline $\begin{array}{l}\text { Palvelutarpeen tyydyttyminen } \\
\text { (yhdistelmämuuttuja) }\end{array}$ & $\begin{array}{l}\text { Palvelujen käyttö } \\
\text { (1: en, ei ole ollut tarvetta) } \\
\text { 2: en, yritin, enkä päässyt } \\
\text { 3: kyllä, 1-2 krt } \\
\text { 4: kyllä, } 3-5 \mathrm{krt} \\
\text { 5: kyllä, yli } 5 \mathrm{krt} \\
\end{array}$ & $\begin{array}{l}\text { Tuen saanti } \\
\text { 1: kyllä paljon } \\
\text { 2: kyllä jonkin verran } \\
\text { 3: en, mutta olisin tarvinnut } \\
\text { (4: en ole tarvinnut) }\end{array}$ \\
\hline 1: pääsy ja tuki $(\mathrm{n}=25652)$ & $3-5$ & $1-2$ \\
\hline 2: pääsy mutta ei tukea $(n=1967)$ & $3-5$ & 3 \\
\hline 3: ei pääsyä mutta tuki $(n=691)$ & 2 & $1-2$ \\
\hline 4: ei pääsyä eikä tukea $(n=657)$ & 2 & 3 \\
\hline
\end{tabular}

Sukupuolta kysyttiin vaihtoehdoilla 1) poika ja 2) tyttö. Kouluastetta tarkasteltiin perusopetuksen 8.- ja 9.-luokkaisten, lukion 1. ja 2. vuoden opiskelijoiden sekä ammatillisten oppilaitosten 1 . ja 2. vuoden opiskelijoiden välillä. Sosioekonomista asemaa tarkasteltiin perheen taloudellisen tilanteen ja äidin koulutusasteen avulla. Perheen taloudellisen tilanteen arvioinnin vastausvaihtoehdot olivat 1) erittäin hyvä, 2) melko hyvä, 3) kohtalainen, 4) melko huono ja 5) erittäin huono. Äidin koulutusastetta kysyttiin vastausvaihtoehdoilla 1) peruskoulu tai vastaava, 2) lukio tai ammatillinen oppilaitos, 3) lukion tai ammatillisen oppilaitoksen lisäksi ammatillisia opintoja ja 4) yliopisto, ammattikorkeakoulu tai muu korkeakoulu. Kuntaryhmityksessä käytettiin luokitusta: 1) kaupunkimaiset kunnat, 2) taajaan asutut kunnat ja 3) maaseutumaiset kunnat. Syntyperää tarkasteltaessa käytettiin 4-luokkaista muuttujaa, joka määritteli ulkomaalaistaustaisuuden nuoren ja vanhempien syntymämaan perusteella seuraaviin luokkiin: 1) suomalainen syntyperä, 2) toinen vanhemmista ulkomaalaistaustainen, 3) ulkomaalaistaustainen, syntynyt Suomessa ja 4) ulkomaalaistaustainen, syntynyt ulkomailla.

\section{TILASTOLLISET MENETELMÄT}

Tässä tutkimuksessa aineiston analyysi toteutettiin ilman sukupuoleen perustuvaa jakoa, mutta sukupuolen yhteys tyydyttymättömään palvelutarpeeseen vakioitiin multinomiaalisessa regressioanalyysissa. Taustamuuttujien sekä tyydyttymättömän palvelutarpeen välistä yhteyttä tutkittiin ristiintaulukoinnin ja $\chi 2$-testin avulla (taulukko 3). Selitettävän muuttujan ollessa 4-luokkainen tutkittiin taustamuuttujien yhteyttä tyydyttymättömään palvelutarpeeseen multinomiaalisella regressioanalyysillä. Regressioanalyysi toteutettiin ensin vakioimattomalla regressiomallilla (taulukko 4), jossa tarkasteltiin erikseen jokaisen selittävän muuttujan yhteyttä koettuun tyydyttymättömään palvelutarpeeseen. Seuraavaksi toteutettiin vakioitu regressiomalli (taulukko 5), jossa tarkasteltiin yhdessä jokaisen selittävän muuttujan yhteyttä koettuun tyydyttymättömään palvelutarpeeseen. Luokka 1 (päässyt palveluihin ja saanut tukea) valittiin referenssiryhmäksi. Tilastollisen merkitsevyyden rajaksi asetettiin arvo $\mathrm{p}<0,001$ aineiston suuren koon vuoksi. Aineiston analyysi toteutettiin tilastollisin menetelmin SPSS Statistics 25.0 -ohjelmalla.

\section{TUTKIMUSTULOKSET}

Tutkimuksen aineisto koostui 28967 nuoren vastauksesta (taulukko 2), joista 52 prosenttia oli 8.- ja 9.-luokkalaisia, 27 prosenttia lukiolaisia ja 21 prosenttia ammatillisen oppilaitoksen opiskelijoita. Vuoden 2017 Kouluterveyskyselyn vastausaktiivisuus oli 8.- ja 9.-luokkalaisten osalta 64 prosenttia. Lukion ja ammatillisten oppilaitosten kohdalla tiedetään arvioidut vastausaktiivisuudet, jotka olivat lukiolaisten osalta 50 prosenttia ja ammatillisen oppilaitoksen opiskelijoiden osalta 40 prosenttia (39).

Tyttöjen (68\%) osuus aineistossa oli huomattavasti poikien (32\%) osuutta suurempi. Yli kolmannes vastaajista (39 \%) ilmoitti äidin koulutusasteeksi yliopiston, ammattikorkeakoulun tai muun korkeakoulun. Vajaa kolmannes nuorista $(30 \%)$ vastasi äidin koulutusasteeksi lukion tai ammatillisen oppilaitoksen ja noin joka neljännen nuoren $(23 \%)$ äidillä oli lukion tai ammatillisen oppilaitoksen lisäksi ammatillisia opintoja. Vajaa kymmenesosa nuorista ( $8 \%$ ) ilmoitti äidillään olevan peruskoulu tai vastaava koulutusaste. Perheen taloudellisen tilanteen koki melko hyväksi vajaa puolet nuorista (42\%) ja kohtalaiseksi vajaa kolmannes nuorista (30\%). Perheen taloudellisen tilanteen koki erittäin hy- 
Taulukko 2. Nuorten taustatekijät kokonaisaineistossa ( $\mathrm{n}=139829)$ ja rajatussa $(\mathrm{n}=28967)$ aineistossa

\begin{tabular}{|c|c|c|}
\hline Taustatekijä & $\begin{array}{l}\text { Kokonaisaineisto }(\mathrm{n}=139829) \\
\%(\mathrm{n})\end{array}$ & $\begin{array}{l}\text { Rajattu aineisto }(\mathrm{n}=28967) \\
\%(\mathrm{n})\end{array}$ \\
\hline $\begin{array}{l}\text { Sukupuoli } \\
\text { Poika } \\
\text { Tyttö }\end{array}$ & $\begin{array}{l}49,2(68333) \\
50,8(70539)\end{array}$ & $\begin{array}{l}31,5(9072) \\
68,5(19720)\end{array}$ \\
\hline $\begin{array}{l}\text { Kouluaste } \\
\text { 8. -9.luokka } \\
\text { Lukio 1. ja 2. vuosi } \\
\text { Ammatillinen oppilaitos 1. ja 2. vuosi }\end{array}$ & $\begin{array}{l}52,7(73680) \\
25,0(34961) \\
22,3(31188)\end{array}$ & $\begin{array}{l}51,9(15035) \\
26,6(7693) \\
21,5(6239)\end{array}$ \\
\hline $\begin{array}{l}\text { Äidin koulutusaste } \\
\text { Peruskoulu tai vastaava } \\
\text { Lukio tai ammatillinen oppilaitos } \\
\text { Lukion tai ammatillisen oppilaitoksen lisäksi } \\
\text { ammatillisia opintoja } \\
\text { Yliopisto, AMK tai muu korkeakoulu }\end{array}$ & $\begin{array}{l}6,3(8019) \\
30,0(38103) \\
23,1(29322) \\
40,7(51676)\end{array}$ & $\begin{array}{l}7,5(2073) \\
30,4(8388) \\
23,4(6442) \\
38,6(10645)\end{array}$ \\
\hline $\begin{array}{l}\text { Perheen taloudellinen tilanne } \\
\text { Erittäin huono } \\
\text { Melko huono } \\
\text { Kohtalainen } \\
\text { Melko hyvä } \\
\text { Erittäin hyvä }\end{array}$ & $\begin{array}{l}1,5(1958) \\
6,4(8487) \\
27,3(36293) \\
44,1(58724) \\
20,7(27599)\end{array}$ & $\begin{array}{l}2,2(633) \\
8,5(2454) \\
30,4(8742) \\
42,3(12149) \\
16,5(4743)\end{array}$ \\
\hline $\begin{array}{l}\text { Kuntaryhmitys } \\
\text { Kaupunkimaiset kunnat } \\
\text { Taajaan asutut kunnat } \\
\text { Maaseutumaiset kunnat }\end{array}$ & $\begin{array}{l}70,4(98380) \\
16,9(23671) \\
12,7(17778)\end{array}$ & $\begin{array}{l}67,5(19551) \\
18,4(5342) \\
14,1(4074)\end{array}$ \\
\hline $\begin{array}{l}\text { Syntyperä } \\
\text { Ulkomaalaistaustainen, syntynyt ulkomailla } \\
\text { Ulkomaalaistaustainen, syntynyt Suomessa } \\
\text { Toinen vanhemmista ulkomaalaistaustainen } \\
\text { Suomalainen syntyperä }\end{array}$ & $\begin{array}{l}3,7(4794) \\
1,8(2330) \\
6,7(8715) \\
87,8(114031)\end{array}$ & $\begin{array}{l}4,6(1278) \\
2,1(583) \\
7,2(2013) \\
86,1(24002)\end{array}$ \\
\hline
\end{tabular}

väksi noin joka kuudes nuori $(17 \%)$. Nuorista noin joka kymmenes vastasi kokevansa perheen taloudellisen tilanteen olevan melko huono ja erittäin huonoksi perheen taloudellisen tilanteen koki kaksi prosenttia nuorista. Enemmistö kyselyyn vastaajista asui kaupunkimaisessa kunnassa $(68 \%)$. Valtaosa vastaajista oli syntyperältään suomalaisia $(86 \%)$. Aineiston frekvenssit ja prosenttiosuudet kokonaisaineiston ja rajatun aineiston osalta on esitetty taulukossa 2.

Aineiston nuorista suurin osa, 89 prosenttia oli päässyt kouluterveydenhoitajan luo ja saanut tukea ja apua. Nuorista seitsemän prosenttia kertoi, että oli päässyt kouluterveydenhoitajan vastaanotolle mutta jäänyt ilman tukea ja apua. Kaksi prosenttia nuorista ei ollut päässyt kouluterveydenhoitajan luo mutta kertoi saaneensa tästä huolimatta tukea ja apua. Kyselyyn vastanneista nuorista kaksi prosenttia ei ollut päässyt kouluterveydenhoitajan palvelujen piiriin eikä saanut tukea ja apua.

Taustatekijöiden yhteyttä nuoren kokemukseen palvelutarpeen tyydyttymisestä tutkittiin aluksi ristiintaulukoinnin avulla (taulukko 3).
Kaikki yhteydet olivat tilastollisesti merkitseviä $(\mathrm{p}<0,001)$. Suurin osa sekä tytöistä että pojista ( $89 \%$ ) oli päässyt kouluterveydenhoitajan vastaanotolle ja saanut tukea $(\mathrm{p}<0,001)$. Pojista ja tytöistä pieni osa $(2 \%)$ ilmoitti että he eivät olleet päässeet kouluterveydenhoitajan vastaanotolle eivätkä olleet saaneet apua. Pojat $(4 \%)$ ilmoittivat tyttöjä $(2 \%)$ useammin saaneensa tukea, vaikka he eivät olleet päässeet kouluterveydenhoitajan vastaanotolle. Tytöt $(7 \%)$ puolestaan kokivat poikia (6\%) hieman useammin jäävänsä ilman tukea kouluterveydenhoitajan vastaanotolle pääsystä huolimatta. Lukiolaiset kokivat hieman peruskoulun ja ammatillisen oppilaitoksen opiskelijoita useammin pääsevänsä kouluterveydenhoitajan vastaanotolle ja saavansa tukea $(\mathrm{p}<0,001)$. 8.- ja 9.-luokkaiset ilmoittivat muiden kouluasteiden nuoria useammin tyydyttymättömästä palvelutarpeesta. Nuorella, jonka äidin koulutusaste oli peruskoulu tai vastaava esiintyi yliopisto, ammattikorkeakoulu- tai muun korkeakoulun tutkinnon omaavan äidin nuorta useammin kokemuksia tyydyttymättömästä palvelutarpeesta $(\mathrm{p}<0,001)$. Esimerkiksi 
Taulukko 3. Taustatekijöiden yhteys nuorten kokemukseen palvelutarpeen tyydyttymisestä kouluterveydenhoitajan palvelujen osalta $(\mathrm{n}=28967)$

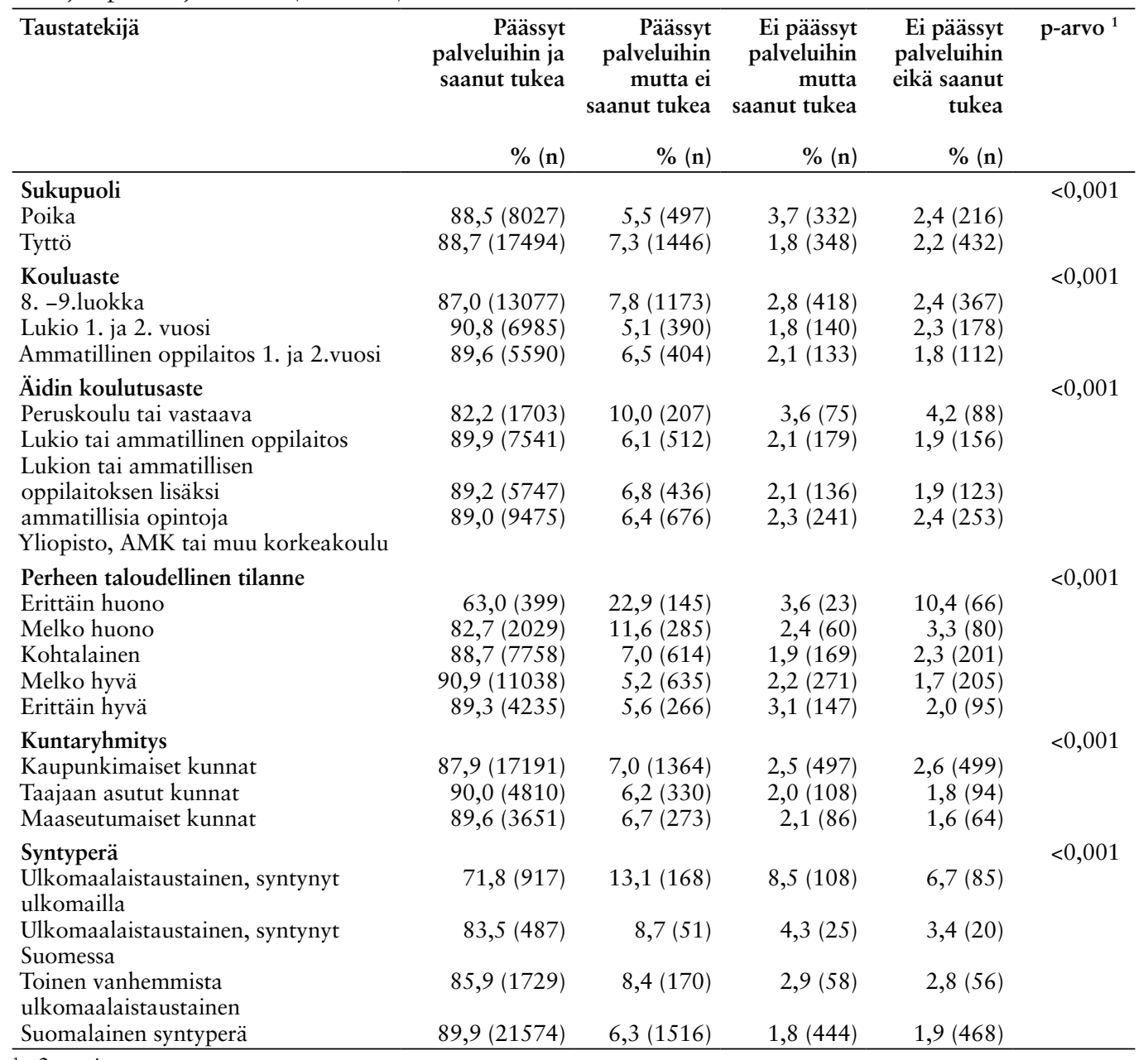

${ }^{1} \chi^{2}$-testi

palveluntarvevertailun luokkaan "ei päässyt palveluihin mutta saanut tukea" kuului peruskoulu tai vastaavan koulutusasteen omaavien äitien nuorista neljä prosenttia ja yliopisto, ammattikorkeakoulu- tai muun korkeakoulun tutkinnon omaavien äitien nuorista kaksi prosenttia.

Perheen taloudellisen tilanteen heikoksi kokeva nuori arvioi perheen taloudellisen tilanteen hyväksi tai kohtalaiseksi kokevia nuoria huomattavasti useammin tyydyttymätöntä palvelutarvetta erityisesti palvelutarvevertailun luokissa "päässyt palveluihin mutta ei saanut tukea" ja "ei päässyt palveluihin eikä saanut tukea" $(\mathrm{p}<0,001)$. Perheen taloudellisen tilanteen erittäin huonoksi kokevista nuorista noin joka viides $(23 \%)$ ilmoitti jääneensä ilman tukea, vaikka oli päässyt kouluterveydenhoitajan vastaanotolle. Perheen taloudellisen tilanteen erittäin hyväksi kokevista nuorista vain kuusi prosenttia kuului edellä mainittuun ryhmään. Kaupunkimaisissa kunnissa asuvat nuoret ilmoittivat jonkin verran taajaan asuttujen kuntien sekä maaseutumaisten kuntien nuoria useammin tyydyttymättömästä palvelutarpeesta $(\mathrm{p}<0,001)$. Ulkomaalaistaustaiset nuoret kokivat suomalaista syntyperää olevien nuoria selkeästi useammin tyydyttymätöntä palvelutarvetta kaikissa palvelutarvevertailuissa $(\mathrm{p}<0,001)$. Esimerkiksi "ei päässyt palveluihin eikä saanut tukea" vastausluokkaan kuului seitsemän prosenttia ulkomaalaistaustaisista nuorista, jotka ovat syntyneet ulkomailla. Suomalaista syntyperää olevista nuorista kyseiseen "ei päässyt palveluihin eikä saanut tukea" vastausluokkaan kuului kaksi prosenttia vastaajista. Ulkomaalaistaus- 
Taulukko 4. Nuorten ristitulosuhteet (OR) tyydyttymättömän palvelutarpeen taustatekijöiden mukaan vakioimattomassa multinominaalisessa regressioanalyysissa (referenssiryhmänä Päässyt palveluihin ja saanut tukea)

\begin{tabular}{|c|c|c|c|c|c|c|c|c|c|}
\hline \multirow[b]{2}{*}{ Taustatekijä } & \multicolumn{3}{|c|}{$\begin{array}{r}\text { Päässyt } \\
\text { palveluihin } \\
\text { mutta ei } \\
\text { saanut tukea } \\
(\mathrm{n}=1831-1967) \\
\end{array}$} & \multicolumn{3}{|c|}{$\begin{array}{r}\text { Ei päässyt } \\
\text { palveluihin } \\
\text { mutta saanut } \\
\text { tukea } \\
(\mathrm{n}=631-691) \\
\end{array}$} & \multicolumn{3}{|c|}{$\begin{array}{r}\text { Ei päässyt } \\
\text { palveluihin } \\
\text { eikä saanut } \\
\text { tukea } \\
(\mathrm{n}=620-657) \\
\end{array}$} \\
\hline & OR & $95 \% \mathrm{lv}$ & p-arvo & OR & $95 \% \mathrm{lv}$ & p-arvo & OR & $95 \% \mathrm{lv}$ & p-arvo \\
\hline $\begin{array}{l}\text { Sukupuoli } \\
\text { Poika } \\
\text { Tyttö }\end{array}$ & $\begin{array}{l}0,75 \\
1,00\end{array}$ & $0,67-0,83$ & $<0,001$ & $\begin{array}{l}2,08 \\
1,00\end{array}$ & $1,79-2,42$ & $<0,001$ & $\begin{array}{l}1,09 \\
1,00\end{array}$ & $0,92-1,29$ & 0,309 \\
\hline $\begin{array}{l}\text { Kouluaste } \\
\text { 8.-9.luokka } \\
\text { Lukio 1. ja 2.vuosi } \\
\text { Ammatillinen } \\
\text { oppilaitos 1. ja 2. vuosi }\end{array}$ & $\begin{array}{l}1,24 \\
0,77 \\
1,00\end{array}$ & $\begin{array}{l}1,10-1,40 \\
0,67-0,89\end{array}$ & $\begin{array}{l}<0,001 \\
<0,001\end{array}$ & $\begin{array}{l}1,34 \\
0,84 \\
1,00\end{array}$ & $\begin{array}{l}1,10-1,64 \\
0,66-1,07\end{array}$ & $\begin{array}{l}0,003 \\
0,161\end{array}$ & $\begin{array}{l}1,40 \\
1,27 \\
1,00\end{array}$ & $\begin{array}{l}1,13-1,74 \\
1,00-1,62\end{array}$ & $\begin{array}{l}0,002 \\
0,049\end{array}$ \\
\hline $\begin{array}{l}\text { Äidin koulutusaste } \\
\text { Peruskoulu tai } \\
\text { vastaava } \\
\text { Lukio tai ammatillinen }\end{array}$ & $\begin{array}{l}1,70 \\
0,95\end{array}$ & $\begin{array}{l}1,45-2,01 \\
0,85-1,07\end{array}$ & $\begin{array}{r}<0,001 \\
0,413\end{array}$ & $\begin{array}{l}1,73 \\
0,93\end{array}$ & $\begin{array}{l}1,33-2,26 \\
0,77-1,14\end{array}$ & $\begin{array}{r}<0,001 \\
0,489\end{array}$ & $\begin{array}{l}1,94 \\
0,78\end{array}$ & $\begin{array}{l}1,51-2,48 \\
0,63-0,95\end{array}$ & $\begin{array}{r}<0,001 \\
0,013\end{array}$ \\
\hline $\begin{array}{l}\text { oppilaitos } \\
\text { Lukion tai } \\
\text { ammatillisen } \\
\text { oppilaitoksen lisäksi } \\
\text { ammatillisia opintoja } \\
\text { Yliopisto, } \\
\text { ammattikorkeakoulu } \\
\text { tai muu korkeakoulu }\end{array}$ & 1,00 & $0,94-1,21$ & 0,335 & 1,00 & $-1,15$ & 0,506 & 1,00 & 1,00 & 0,047 \\
\hline $\begin{array}{l}\text { Perheen taloudellinen } \\
\text { tilanne } \\
\text { Erittäin huono } \\
\text { Melko huono } \\
\text { Kohtalainen } \\
\text { Melko hyvä } \\
\text { Erittäin hyvä }\end{array}$ & $\begin{array}{l}5,79 \\
2,24 \\
1,26 \\
0,92 \\
1,00\end{array}$ & $\begin{array}{l}4,61-7,26 \\
1,88-2,67 \\
1,09-1,46 \\
0,79-1,06\end{array}$ & $\begin{array}{r}<0,001 \\
<0,001 \\
0,002 \\
0,243\end{array}$ & $\begin{array}{l}1,66 \\
0,85 \\
0,63 \\
0,71 \\
1,00\end{array}$ & $\begin{array}{l}1,06-2,61 \\
0,63-1,16 \\
0,50-0,79 \\
0,58-0,87\end{array}$ & $\begin{array}{r}0,028 \\
0,303 \\
<0,001 \\
0,001\end{array}$ & $\begin{array}{l}7,37 \\
1,76 \\
1,16 \\
0,83 \\
1,00\end{array}$ & $\begin{array}{r}5,30-10,26 \\
1,30-2,38 \\
0,90-1,48 \\
0,65-1,06\end{array}$ & $\begin{array}{r}<0,001 \\
<0,001 \\
0,253 \\
0,132\end{array}$ \\
\hline $\begin{array}{l}\text { Kuntaryhmitys } \\
\text { Kaupunkimaiset } \\
\text { kunnat } \\
\text { Taajaan asutut kunnat } \\
\text { Maaseutumaiset } \\
\text { kunnat }\end{array}$ & $\begin{array}{l}1,06 \\
0,92 \\
1,00\end{array}$ & $\begin{array}{l}0,93-1,21 \\
0,78-1,08\end{array}$ & $\begin{array}{l}0,388 \\
0,310\end{array}$ & $\begin{array}{l}1,23 \\
\\
0,95 \\
1,00\end{array}$ & $\begin{array}{l}0,97-1,55 \\
0,72-1,27\end{array}$ & $\begin{array}{l}0,083 \\
0,743\end{array}$ & $\begin{array}{l}1,66 \\
1,12 \\
1,00\end{array}$ & $\begin{array}{l}1,27-2,15 \\
0,81-1,54\end{array}$ & $\begin{array}{r}<0,001 \\
0,506\end{array}$ \\
\hline $\begin{array}{l}\text { Syntyperä } \\
\text { Ulkomaalaistaustainen, } \\
\text { syntynyt ulkomailla }\end{array}$ & 2,61 & $2,19-3,10$ & $<0,001$ & 5,72 & $4,59-7,13$ & $<0,001$ & 4,27 & $3,36-5,43$ & $<0,001$ \\
\hline $\begin{array}{l}\text { Ulkomaalaistaustainen, } \\
\text { syntynyt Suomessa }\end{array}$ & 1,49 & $1,11-2,00$ & 0,008 & 2,49 & $1,65-3,77$ & $<0,001$ & 1,89 & $1,20-2,99$ & 0,006 \\
\hline $\begin{array}{l}\text { Toinen vanhemmista } \\
\text { ulkomaalaistaustainen } \\
\text { Suomalainen syntyperä }\end{array}$ & $\begin{array}{l}1,40 \\
1,00\end{array}$ & $1,19-1,65$ & $<0,001$ & $\begin{array}{l}1,63 \\
1,00\end{array}$ & $1,23-2,15$ & 0,001 & $\begin{array}{l}1,49 \\
1,00\end{array}$ & $1,13-1,98$ & 0,005 \\
\hline
\end{tabular}

Päässyt palveluihin ja saanut tukea referenssiryhmänä

$\mathrm{OR}=$ ristitulosuhde, lv=luottamusväli, tilastollinen merkitsevyystaso $\mathrm{p}<0,001$

taiset nuoret, jotka olivat syntyneet ulkomailla (9\%) kokivat suomalaista syntyperää olevaa nuoria $(2 \%)$ useammin saaneensa tukea, vaikka he eivät olleet päässeet kouluterveydenhoitajan vastaanotolle.

Taulukoissa 4 ja 5 on kuvattuna multinomiaalisen regressioanalyysin tulokset vakioimattoman ja vakioidun mallin mukaan. Vakioimattomassa regressiomallissa havaittiin tilastollisesti merkitseviä yhteyksiä $(\mathrm{p}<0,001)$ koettuun tyydyttymättömään palvelutarpeeseen kaikissa selittävissä muuttujissa, mutta tilastollisesti merkitsevät yhteydet vaihtelivat muuttujittain eri palvelutarvevertailujen (päässyt palveluihin mutta ei saanut tukea, ei päässyt palveluihin mutta saanut tukea sekä ei päässyt palveluihin eikä saanut tukea) vä- 
Taulukko 5. Nuorten ristitulosuhteet (OR) tyydyttymättömän palvelutarpeen taustatekijöiden mukaan vakioidussa multinominaalisessa regressioanalyysissa (referenssiryhmänä Päässyt palveluihin ja saanut tukea)

\begin{tabular}{|c|c|c|c|c|c|c|c|c|c|}
\hline \multirow[b]{2}{*}{ Taustatekijä } & & \multirow{3}{*}{$\begin{array}{r}\text { Päässyt } \\
\text { palveluihin } \\
\text { mutta ei } \\
\text { saanut } \\
\text { tukea } \\
(\mathrm{n}=1759) \\
95 \% \mathrm{lv}\end{array}$} & \multirow[b]{3}{*}{ p-arvo } & \multicolumn{3}{|c|}{$\begin{array}{r}\text { Ei päässyt } \\
\text { palveluihin } \\
\text { mutta } \\
\text { saanut } \\
\text { tukea } \\
(\mathrm{n}=591)\end{array}$} & \multicolumn{3}{|c|}{$\begin{array}{r}\text { Ei päässyt } \\
\text { palveluihin } \\
\text { eikä saanut } \\
\text { tukea } \\
(\mathrm{n}=588)\end{array}$} \\
\hline & & & & & & & & & \\
\hline Sukupuoli & OR & & & OR & $95 \% \mathrm{lv}$ & p-arvo & OR & $95 \% \mathrm{lv}$ & p-arvo \\
\hline $\begin{array}{l}\text { Poika } \\
\text { Tyttö }\end{array}$ & $\begin{array}{l}0,67 \\
1,00\end{array}$ & $0,60-0,75$ & $<0,001$ & $\begin{array}{l}1,72 \\
1,00\end{array}$ & $1,45-2,03$ & 0,001 & $\begin{array}{l}0,96 \\
1,00\end{array}$ & $0,80-1,15$ & 0,664 \\
\hline $\begin{array}{l}\text { Kouluaste } \\
\text { 8.-9.luokka } \\
\text { Lukio 1. ja 2.vuosi } \\
\text { Ammatillinen } \\
\text { oppilaitos 1. ja 2. vuosi }\end{array}$ & $\begin{array}{l}1,38 \\
0,85 \\
1,00\end{array}$ & $\begin{array}{l}1,21-1,57 \\
0,73-1,00\end{array}$ & $\begin{array}{r}<0,001 \\
0,046\end{array}$ & $\begin{array}{l}1,62 \\
1,18 \\
1,00\end{array}$ & $\begin{array}{l}1,29-2,03 \\
0,89-1,55\end{array}$ & $\begin{array}{r}<0,001 \\
0,252\end{array}$ & $\begin{array}{l}1,70 \\
1,67 \\
1,00\end{array}$ & $\begin{array}{l}1,34-2,15 \\
1,28-2,17\end{array}$ & $\begin{array}{l}<0,001 \\
<0,001\end{array}$ \\
\hline $\begin{array}{l}\text { Äidin koulutusaste } \\
\text { Peruskoulu tai vastaava } \\
\text { Lukio tai ammatillinen } \\
\text { oppilaitos }\end{array}$ & $\begin{array}{l}1,11 \\
0,86\end{array}$ & $\begin{array}{l}0,92-1,33 \\
0,76-0,97\end{array}$ & $\begin{array}{l}0,265 \\
0,018\end{array}$ & $\begin{array}{l}1,14 \\
1,00\end{array}$ & $\begin{array}{l}0,85-1,55 \\
0,81-1,23\end{array}$ & $\begin{array}{l}0,387 \\
0,996\end{array}$ & $\begin{array}{l}1,08 \\
0,78\end{array}$ & $\begin{array}{l}0,81-1,45 \\
0,63-0,97\end{array}$ & $\begin{array}{l}0,593 \\
0,022\end{array}$ \\
\hline $\begin{array}{l}\text { Lukion tai ammatillisen } \\
\text { oppilaitoksen lisäksi } \\
\text { ammatillisia opintoja }\end{array}$ & 0,98 & $0,86-1,11$ & 0,723 & 1,02 & $0,82-1,28$ & 0,840 & 0,80 & $0,64-1,01$ & 0,057 \\
\hline $\begin{array}{l}\text { Yliopisto, } \\
\text { ammattikorkeakoulu tai } \\
\text { muu korkeakoulu }\end{array}$ & 1,00 & & & 1,00 & & & 1,00 & & \\
\hline $\begin{array}{l}\text { Perheen taloudellinen } \\
\text { tilanne }\end{array}$ & & & & & & & & & \\
\hline Erittäin huono & 5,22 & $4,05-6,74$ & $<0,001$ & 0,97 & $0,55-1,68$ & 0,902 & 6,37 & $4,36-9,29$ & $<0,001$ \\
\hline Melko huono & 2,44 & $2,02-2,95$ & $<0,001$ & 1,12 & $0,80-1,55$ & 0,517 & 2,10 & $1,51-2,92$ & $<0,001$ \\
\hline Kohtalainen & 1,36 & $1,16-1,60$ & $<0,001$ & 0,79 & $0,62-1,01$ & 0,062 & 1,45 & $1,11-1,89$ & 0,007 \\
\hline Melko hyvä & 0,99 & $0,85-1,16$ & 0,904 & 0,88 & $0,71-1,10$ & 0,268 & 0,97 & $0,75-1,27$ & 0,844 \\
\hline Erittäin hyvä & 1,00 & & & 1,00 & & & 1,00 & & \\
\hline Kuntaryhmitys & & & & & & & & & \\
\hline Kaupunkimaiset kunnat & 1,12 & $0,97-1,29$ & 0,138 & 1,12 & $0,87-1,44$ & 0,368 & 1,79 & $1,35-2,38$ & $<0,001$ \\
\hline Taajaan asutut kunnat & 0,96 & $0,80-1,14$ & 0,625 & 1,00 & $0,74-1,36$ & 0,985 & 1,23 & $0,88-1,74$ & 0,231 \\
\hline Maaseutumaiset kunnat & 1,00 & & & 1,00 & & & 1,00 & & \\
\hline $\begin{array}{l}\text { Syntyperä } \\
\text { Ulkomaalaistaustainen, } \\
\text { syntynyt ulkomailla }\end{array}$ & 2,04 & $1,65-2,51$ & $<0,001$ & 4,79 & $3,69-6,21$ & $<0,001$ & 3,23 & $2,42-4,31$ & $<0,001$ \\
\hline $\begin{array}{l}\text { Ulkomaalaistaustainen, } \\
\text { syntynyt Suomessa }\end{array}$ & 1,40 & $1,02-1,92$ & 0,035 & 1,98 & $1,26-3,12$ & 0,003 & 1,78 & $1,12-2,83$ & 0,015 \\
\hline $\begin{array}{l}\text { Toinen vanhemmista } \\
\text { ulkomaalaistaustainen }\end{array}$ & 1,30 & $1,09-1,54$ & 0,004 & 1,55 & $1,16-2,07$ & 0,003 & 1,33 & $1,00-1,78$ & 0,054 \\
\hline Suomalainen syntyperä & 1,00 & & & 1,00 & & & 1,00 & & \\
\hline
\end{tabular}

Päässyt palveluihin ja saanut tukea referenssiryhmänä

$\mathrm{OR}=$ ristitulosuhde, lv=luottamusväli, tilastollinen merkitsevyystaso $\mathrm{p}<0,001$

lillä verrattuna ryhmään, joka oli päässyt palvelujen piiriin sekä saanut tukea ja apua (päässyt palveluihin ja saanut tukea). Vakioimattomassa regressiomallissa tilastollisesti merkitsevä yhteys koettuun tyydyttymättömään palvelutarpeeseen kaikissa palvelutarvevertailuissa havaittiin olevan äidin peruskouluasteisella koulutuksella sekä nuoren ulkomaalaistaustaisuudella (syntynyt ulkomailla). Täten ne nuoret, joiden äidillä oli peruskoulutausta, kokivat tyydyttymätöntä palvelutarvetta yleisemmin kuin ne nuoret, joi- den äideillä oli yliopistokoulutus. Myös nuoret, jotka olivat ulkomaalaistaustaisia ja syntyneet ulkomailla kokivat tyydyttymätöntä palvelutarvetta suomalaista syntyperää olevia nuoria yleisemmin.

Pojat kokivat tyttöjä harvemmin jäävänsä ilman tukea palvelujen piiriin päästyään, mutta pojat ilmoittivat tyttöjä yleisemmin myös saavansa apua, vaikka he eivät olisi saavuttaneet palvelua. 8.- ja 9.-luokkalaiset kokivat ammatillisen oppilaitoksen opiskelijoita useammin jäävänsä ilman 
tukea kouluterveydenhoitajan vastaanotolle päästyään, kun taas lukiolaiset raportoivat ammatillisen oppilaitoksen opiskelijoita harvemmin jäävänsä ilman tukea kouluterveydenhoitajan vastaanotolle päästyään. Perheen taloudellisen tilanteen heikoksi kokeneet nuoret ilmaisivat taloudellisen tilanteen hyväksi kokevia nuoria useammin tyydyttymätöntä palvelutarvetta. Tämä näkyi siinä, että taloudellisen tilanteen heikoksi kokeneet nuoret raportoivat useammin, että he joko pääsivät vastaanotolle mutta eivät saaneet tukea tai jäivät sekä palvelujen ulkopuolelle että ilman tukea. Nuoret, jotka asuivat kaupunkimaisissa kunnissa, ilmaisivat maaseutumaisissa kunnissa asuvia nuoria hieman useammin, että he eivät päässeet vastaanotolle eivätkä saaneet tukea.

Vakioidussa regressiomallissa äidin koulutusasteen yhteys koettuun tyydyttymättömään palvelutarpeeseen ei säilynyt tilastollisesti merkitsevänä. Nuoren ulkomaalaistaustaisuuden (syntynyt ulkomailla) yhteys koettuun tyydyttymättömään palvelutarpeeseen sen sijaan säilyi tilastollisesti merkitsevänä kaikissa palvelutarvevertailun luokissa myös sekoittavien tekijöiden vakioinnin jälkeen. Sukupuolen yhteys koettuun tyydyttymättömään palvelutarpeeseen säilyi samansuuntaisena vakioimattoman mallin tulosten kanssa myös sekoittavien tekijöiden vakionnin jälkeen palvelutarvevertailun "päässyt palveluihin mutta ei saanut tukea"-luokassa, eli pojat ilmaisivat edelleen tyttöjä harvemmin jäävänsä ilman tukea palvelujen piiriin päästyään. Myös kouluasteen yhteys koettuun tyydyttymättömään palvelutarpeeseen säilyi, kun sekoittavat tekijät vakioitiin: 8.-9.-luokkalaiset raportoivat tyydyttymätöntä palvelutarvetta ammattikoululaisia useammin jokaisessa palvelutarvevertailussa. Lukiolaiset kokivat ammattikoululaisia yleisimmin, että he eivät päässeet vastaanotolle eivätkä saaneet tukea.

Vakioidussa regressiomallissa perheen heikon taloudellisen tilanteen yhteys tyydyttymättömään palvelutarpeeseen säilyi tilastollisesti merkitsevänä. Perheen taloudellisen tilanteen erittäin huonoksi kokeneet nuoret raportoivat perheen taloudellisen tilanteen erittäin hyväksi kokevia nuoria useammin, että he joko pääsivät vastaanotolle mutta eivät saaneet tukea tai he eivät päässeet vastaanotolle eivätkä saaneet tukea. Asuinpaikan yhteys nuoren kokemaan tyydyttymättömään palvelutarpeeseen säilyi ennallaan myös sekoittavien tekijöiden vakioinnin jälkeen eli kaupunkimaisissa kunnissa asuvat nuoret raportoivat maaseutumaisissa kunnissa asuvia nuoria useammin, etteivät he olleet päässeet vastaanotolle eivätkä saaneet tukea.

\section{POHDINTA}

Nuorista noin joka kymmenes $(11 \%)$ oli kokenut tyydyttymätöntä palvelutarvetta. Tulos on samansuuntainen aiemman tutkimustiedon kanssa $(16,18,31,40)$. Tämän tutkimuksen tulosten mukaan nuoren sukupuolella, sosioekonomisella asemalla, kouluasteella, kuntaryhmityksellä sekä syntyperällä havaittiin olevan tilastollisesti merkitsevä yhteys nuoren kokemaan tyydyttymättömään palvelutarpeeseen. Samansuuntaisia tuloksia on saatu myös aiemmissa tyydyttymätöntä palvelutarvetta tarkastelevissa tutkimuksissa $(18,25)$ ja katsauksessa $(29)$.

Tytöt kokivat poikia useammin tyydyttymätöntä palvelutarvetta siten, että he ilmaisivat jääneensä ilman tukea ja apua, vaikka pääsivät kouluterveydenhoitajan vastaanotolle. Pojat puolestaan kokivat tyttöjä useammin saavansa tukea ja apua, vaikka he eivät saavuttaneet kouluterveydenhoitajan palveluita. Sukupuolen yhteyttä koettuun tyydyttymättömään palvelutarpeeseen tarkasteltaessa tulee ottaa huomioon, että tyydyttymättömän palvelutarpeen raportointi perustui nuoren omaan arvioon. Sukupuolten välinen ero tyydyttymättömän palvelutarpeen kokemisessa oli melko pieni ja ero voi selittyä tyttöjen matalammalla kynnyksellä raportoida kokemuksiaan tyydyttymättömästä palvelutarpeesta (18). Tytöt myös käyttävät opiskeluhuollon palveluja poikia useammin (41), jolloin on todennäköisempää, etteivät tytöt pääse opiskeluhuollon palvelujen piiriin aina tuen ja avun tarpeen ilmaantuessa.

Aiempien tutkimusten tulosten kanssa samansuuntaisesti tässä tutkimuksessa havaittiin perheen heikon taloudellisen tilanteen olevan yhteydessä koettuun tyydyttymättömään palvelutarpeeseen $(18,25,29,34)$. Ne nuoret, jotka kokivat perheen taloudellisen tilanteen joko erittäin tai melko huonoksi, raportoivat perheen taloudellisen tilanteen erittäin hyväksi kokevia nuoria useammin, että he joko pääsivät vastaanotolle mutta eivät saaneet tukea tai jäivät sekä palvelujen ulkopuolelle että ilman tukea. On mahdollista, että talousvaikeuksissa olevat nuoret odottaisivat kouluterveydenhoitajan ottavan 
esille taloudellisen hyvinvoinnin kysymyksiä ja tuen tarvetta. Myös joko nuoren tai hänen vanhempansa ulkomaalaistaustaisuuden havaittiin olevan yhteydessä koettuun tyydyttymättömään palvelutarpeeseen $(16,18,25,29,34,40,42)$. Tämän tutkimuksen tuloksista nousivat esille lisäksi kouluasteen sekä kuntaryhmityksen yhteys koettuun tyydyttymättömään palvelutarpeeseen. Peruskoulun 8.- ja 9.-luokkalaiset $(2,4 \%)$ sekä lukiolaiset $(2,3 \%)$ raportoivat ammatillisen oppilaitoksen opiskelijoita $(1,8 \%)$ useammin tyydyttymätöntä palvelutarvetta. Samansuuntainen tulos on saatu opiskeluhuollon saavutettavuuden valtakunnallisessa arvioinnissa, jossa helpoimmaksi terveydenhoitajan vastaanotolle pääsyn kokivat ammatillisen oppilaitoksen opiskelijat (19). Kyseisen arvioinnin pohjana on käytetty Kouluterveyskyselyn vuoden 2015 aineistoa. Nuoren asuinpaikan yhteyttä tyydyttymättömään palvelutarpeeseen tutkittaessa tuloksista nousi esiin, että kaupungissa asuvat nuoret kokivat maalla tai taajamassa asuvia nuoria useammin tyydyttymätöntä palvelutarvetta. Opiskeluhuollon palvelujen henkilöstövoimavaroissa on tunnistettu aiemmin alueellisia eroja $(13,19)$.

Tutkimus tuotti uutta kansallista tietoa nuorten tyydyttymättömän palvelutarpeen esiintyvyydestä sekä siihen yhteydessä olevista sosioekonomisista ja -demografisista tekijöistä. Valtaosa Kouluterveyskyselyyn vastanneista nuorista voi hyvin. Vastaajien joukossa on kuitenkin myös nuoria, joilla esiintyy yksi tai useampi pahoinvointia lisäävä taustatekijä, jolloin riskinä on pahoinvoinnin ja vähäosaisuuden polarisoituminen näille nuorille $(4,5$.).

Tämän tutkimuksen vahvuutena on sen perustuminen kattavaan valtakunnalliseen kokonaistutkimukseen (43). Tutkimuksen vahvuutena on myös aineiston suuri koko, jolloin tulosten sattumanvaraisuus vähenee ja reliabiliteetti vahvistuu (44). Tutkimuksen mahdollisena heikkoutena on se, että kysely on nuorten itsearvio, joten esimerkiksi nuoren antama arvio perheen taloudellisesta tilanteesta voi poiketa todellisesta tilanteesta. Toisaalta kyseessä on nuoren aito kokemus perheensä taloudellisesta toimeentulosta ja tämän kokemuksen merkityksellisyys tulee ottaa huomioon. Perheen taloudellisella tilanteella todettiin tässä tutkimuksessa olevan tilastollisesti merkitsevä yhteys nuoren kokemaan tyydyttymättömään palvelutarpeeseen. Tulosten luo- tettavuuden arvioinnissa tulee ottaa huomioon nuoren itsensä antama arvio ja tämän arvion pohjautuminen kokemukseen eikä esimerkiksi rekistereistä saatavaan tietoon.

Kouluterveyskyselyn vastausaktiivisuutta voidaan pitää kohtalaisena (39), mutta tutkimuksen vastaajakatoa pitää tarkastella myös siitä näkökulmasta, että kyselyyn vastaamatta jättäneiden joukossa on myös nuoria, joilla on keskimääräistä enemmän ongelmia ja vaikeuksia elämän eri osa-alueilla (43). Tällöin vastauksista jäävät puuttumaan näiden nuorten vastaukset, jolloin kyselyn tulokset voivat jäädä todellisuutta myönteisimmiksi. Tuloksia yleistettäessä tulee myös muistaa, että valtaosa Kouluterveyskyselyyn osallistuneista nuorista vastasi päässeensä kouluterveydenhoitajan vastaanotolle sekä saaneensa tukea ja apua eli valtaosa nuorista ei ollut kokenut tyydyttymätöntä palvelutarvetta.

Tutkimustietoa lasten ja nuorten tuen ja avun saamisesta tai palvelujen tarpeisiin vastaavuudesta on saatavilla vain vähän, joten aihetta tulisi tutkia lisää. Tämän tutkimuksen tuloksista nousi esille erityisesti syntyperän sekä perheen taloudellisen tilanteen yhteys koettuun tyydyttymättömään palvelutarpeeseen, joten erityisesti näihin tekijöihin suuntautuva tutkimus voisi tuottaa arvokasta lisätietoa nuorten palvelujen saatavuudesta sekä avun saamiseen yhteydessä olevista tekijöistä. Perheen sosioekonomisen aseman tutkiminen muuten kuin nuorelta itseltään kysyttynä voisi lisätä saatujen tulosten luotettavuutta ja yleistettävyyttä. Nuorten kokemaa tyydyttymätöntä palvelutarvetta voisi tutkia myös muiden, tämän tutkimuksen ulkopuolelle rajattujen opiskeluhuollon ammattilaisten näkökulmasta.

Nuorten kokeman tyydyttymättömän palvelutarpeen tutkiminen mahdollistaisi näytön saamisen vuonna 2014 voimaan astuneen oppilas- ja opiskelijahuoltolain vaikutuksista opiskeluhuollon palvelujen saatavuuteen ja kattavuuteen kansallisella tasolla. Jokaisella nuorella on oikeus laadukkaisiin opiskeluhuollon palveluihin ja tämän oikeuden toteutumista voidaan ohjata sekä seurata lakien, asetusten ja selvitysten kautta.

\section{JOHTOPÄÄTÖKSET}

Tutkimuksen päätuloksena on, että tietyt sosioekonomiset ja sosiodemografiset tekijät ovat yhteydessä nuorten kokemaan tyydyttymättömään palvelutarpeeseen kouluterveydenhoitajan palve- 
luista. Näitä tekijöitä ovat perheen taloudellinen tilanne (erittäin huono, melko huono), nuoren kouluaste (8. ja 9. luokka ja lukio), nuoren asuinpaikka (kaupunki) sekä nuoren syntyperä (ulkomaalaistausta ja syntynyt ulkomailla). Erityisesti perheen huonon taloudellisen tilanteen sekä nuoren ulkomaalaistaustaisuuden yhteys koettuun tyydyttymättömään palvelutarpeeseen nousivat esille tuloksista.

Tunnistamalla nämä tietyt riskitekijät voidaan tehokkaammin kohdentaa tukea ja apua näille nuorille ja parantaa heidän mahdollisuuksia saada tukea ja apua tunnistettuun tarpeeseen sekä pienentää nuorten riskiä jäädä palvelujen ulkopuolelle. Tyydyttymättömään palvelutarpeeseen yhteydessä olevien tekijöiden tunnistaminen auttaa myös kehittämään nuorten palvelujärjes- telmän toimintaa, esimerkiksi opiskeluhuollon palveluja.

\section{RAHOITTAJAT:}

Tutkimusta ei ole rahoittanut mikään taho.

\section{KIRJOITTAJIEN KONTRIBUUTIOT:}

Välkkilä osallistui tutkimuksen suunnitteluun, analysoi aineiston ja vastasi käsikirjoituksen kirjoittamisesta. Joronen osallistui tutkimuksen suunnitteluun, osallistui käsikirjoituksen kirjoittamiseen ja antoi kriittisiä ehdotuksia kirjoittamisprosessin aikana. Koivisto osallistui tilastollisten analyysien tekemiseen ja antoi kriittisiä ehdotuksia käsikirjoituksesta. Kanste osallistui tutkimuksen suunnitteluun, tutkimusaineiston hankintaan ja antoi kriittisiä ehdotuksia käsikirjoituksesta.

Välkkilä, L., Joronen, K., Koivisto, A-M., Kanste,O. School health nurse services: the association of sociodemographic factors with adolescents' experiences Sosiaalilääketieteellinen aikakauslehti- Journal of Social Medicine 2020: 57: I55-I67.

Sociodemographic and socioeconomic factors have been shown to be associated with the availability of adolescents' services and adolescents' experience of services. The aim of this study was to describe the associations between the background factors and the adolescents' unmet service need for school health nurse services.

The study material was based on data from the School Health Promotion study 2017 (n=139 829). Adolescents who reported no need for school health nurse services were excluded from the data. After the exclusion, altogether 28967 responses of 8 th and 9 th graders and 1 st and 2 nd year students of upper secondary schools and vocational schools were included in the analysis.

To study the unmet service need, questions concerning the availability of and support from the school health nurse services were combined into one new variable with four categories: 1) access to services and support, 2) access to services but no support, 3 ) no access to services but support and 4) no access to services and no support. The data were analyzed by cross-tabulation, $\chi 2$-tests and multinomial logistic regression analysis.

The results showed that 11 percent of the young people reported unmet need for school health nurse services. All background factors were statistically significantly associated with the unmet service need. Especially immigrant background and self-rated low economic situation in the family were associated with unmet service need. The results show that Finnish adolescents are not in an equal position in the availability of school health nurse services

Keywords: adolescents, school health services, availability of services, unmet need for services

Saapunut 19.06.2019

Hyväksytty 28.01.2020

\section{LÄHTEET}

(1) Tilasto- ja indikaattoripankki Sotkanet.fi. 2019. Väestö 1-vuotisikäryhmittäin 31.12.2018. Luettu 19.2.2019. https://sotkanet.fi/sotkanet/fi/taulukk $\mathrm{o} /$ ? indicator=s7YItjbRMwQA\&region $=\mathrm{s} 07 \mathrm{MBA}$ $\mathrm{A}=$ \&year $=$ sy $6 \mathrm{rAAA}=\&$ gender $=\mathrm{t} \& \mathrm{abs}=\mathrm{f} \&$ color $=$ f\&buildVersion $=3.0$-SNAPSHOT\&buildTimesta $\mathrm{mp}=201802280718$
(2) Aira T, Hämylä R, Kannas L, ym. 2014. Lasten hyvinvoinnin tila kansallisten indikaattoreiden kuvaamana. Lapsiasiavaltuutetun toimiston julkaisuja 2014:4. Luettu 11.1.2018 http:// lapsiasia.fi/wp-content/uploads/2015/03/lasten_ hyvinvoinnin_tila.pdf 
(3) Paananen R, Ristikari T, Merikukka M, ym. 2012. Lasten ja nuorten hyvinvointi. Kansallinen syntymäkohortti1987- tutkimusaineiston valossa. Luettu 15.1.2018. https://www.julkari. fi/bitstream/handle/10024/102984/THL_ RAPO52_2012_web.pdf

(4) Kallunki V, Lehtonen O. 2012. Nuorten aikuisten elämäntyytyväisyyden osatekijät hyvinvoinnin eri tasoilla. Yhteiskuntapolitiikka 2012;77: 359-374.

(5) Pelkonen M, Hakulinen-Viitanen T, HietanenPeltola M, ym. 2013. Hyvinvointia useammille - Lasten ja nuorten palvelut uudistuvat. Luettu 11.1.2018. https://www.julkari.fi/ bitstream/handle/10024/110796/URN_ ISBN_978-952-00-3452-8.pdf? sequence=1

(6) Hale D, Viner Russell. How adolescent health influences education and employment: investigating longitudinal associations and mechanisms. Journal of epidemiology $\&$ community health 2018;72: 465-470. doi: 10.1136/jech-2017-209605

(7) Gutiérrez-García RA, Benjet C, Borges G, ym. NEET adolescents grown up: eight-year longitudinal follow-up of education, employment and mental health from adolescence to early adulthood in Mexico City. Eur Child Adolesc Psychiatry 2017;26: 1459-1469. doi: 10.1007/s00787-017-1004-0

(8) Education at a Glance. 2018. OECD indicators. Luettu 21.1.2019

https://read.oecd-ilibrary.org/education/ education-at-a-glance-2018_eag-2018-en\#page1

(9) OECD. 2018. Youth not in employment, education or training (NEET). Luettu 13.3.2019. https://data.oecd.org/youthinac/youth-not-inemployment-education-or-training-neet.htm

(10) Sosiaali- ja terveysministeriö 3. 2011. Sosiaalisesti kestävä Suomi. Sosiaali- ja terveyspolitiikan strategia. Luettu 19.2.2019. http://julkaisut.valtioneuvosto.fi/bitstream/ handle/10024/73418/URN\%3ANBN\%3Afife201504223250.pdf?sequence

(11) Wiss K, Halme N, Hietanen-Peltonen M, ym. Perusopetuksen opiskeluhuollon tilannekuva 2017 - Yhdenvertaisuus haasteena sekä yksilökohtaisessa että yhteisöllisessä työssä. 2017. Luettu 11.1.2018. http://www. julkari.fi/bitstream/handle/10024/135219/ TuTi_Opiskeluhuollon\%20tilannekuva_final. pdf? sequence $=1$

(12) Perälä M-L, Hietanen-Peltola M, Halme, N, ym. Monialainen opiskeluhuolto ja sen johtaminen, Tampere. Juvenes Print-Suomen Yliopistopaino Oy. 2015, 12, 18.

(13) Wiss K, Ståhl T, Saaristo V, ym. Terveydenhoitajat, lääkärit, psykologit ja kuraattorit peruskouluissa 2008-2015. Suomen Lääkärilehti 2017;72: 127-135.

(14) Terveyden ja hyvinvoinnin laitos 6. 2014. Kouluterveydenhuolto. Luettu 20.2.2019. https://thl.fi/fi/web/lapset-nuoret-japerheet/peruspalvelut/opiskeluhuolto/ kouluterveydenhuolto
(15) Council on School Health. Role of the School Nurse in Providing School Health Services. Pediatrics 2008;121: 1052-1056. doi: 10.1542/peds.2008-0382

(16) Kivimäki H, Saaristo V, Wiss K, ym. Access to a school health nurse and adolescent health needs in the universal school health service in Finland. Scandinavian Journal of Caring Sciences 2019;33: 165-175. doi: https://doi.org/10.1111/scs.12617

(17) Hammarberg L, Klemetti R. 2016. Nuorten palvelujen järjestämisen malleja MannerSuomessa. Luettu 10.11.2018 http://www.julkari.fi/bitstream/ handle/10024/131367/URN ISBN_978-952-302-7503.pdf? sequence=1

(18) Kanste O, Halme N, Sainio P. Toimintarajoitteisilla nuorilla tyydyttymättömän tuen ja avun tarvetta koulu- ja opiskeluterveydenhuollosta. Sosiaalilääketieteellinen aikakauslehti 2019;36: 3-14. doi: 10.23990/sa.72989

(19) Patio 2. 2015. Opiskeluhuollon riittävyys. Millainen on nuorten mielenterveys ja miten he käyttävät opiskeluhuoltopalveluja ja kokevat niiden saavutettavuuden? Luettu 20.2.2019. https://www.patio.fi/web/pepa-2015-lsavi/ opiskeluhuollon-saavutettavuus

(20) Wiss K, Hakamäki P, Hietanen Peltola M, ym. 2016. Hyvinvoinnin ja terveyden edistäminen peruskouluissa - TEA 2015. Tilastokatsaus 2/2016. Luettu 21.2.2019. http://www.julkari.fi/bitstream/ handle/10024/130509/ Tilastokatsaus_peruskoulut_2016_nett. pdf? sequence $=1$ \& is Allowed $=y$

(21) Sosiaali- ja terveysministeriö 1. Lapsi- ja perhepalveluiden muutosohjelma (LAPE). Luettu 10.2.2018 http://stm.fi/hankkeet/lapsi-ja-perhepalvelut

(22) Terveyden ja hyvinvoinnin laitos 1. 2017. Lapsija perhepalveluiden muutosohjelma (LAPE). Luettu 10.1.2018.

https://www.thl.fi/fi/tutkimus-ja-asiantuntijatyo/ hankkeet-ja-ohjelmat/lapsi-ja-perhepalveluidenmuutosohjelma-lape

(23) Sosiaali- ja terveysministeriö 2. Lapsi- ja perhepalveluiden muutosohjelma-hankesuunnitelma. Luettu 10.2.2018. http://stm.fi/documents/1271139/1953486/ Hankesuunnitelma_Lapsi-ja\%20 perhepalveluiden \%20muutosohjelma.pdf

(24) WHO. World health organization. 2002. Adolescent friendly health services. Luettu 21.2.2019. https://apps.who.int/iris/bitstream/ handle/10665/67923/WHO_FCH CAH_02.14.pdf;jsessionid $=\overline{5}$ DE8F5A900 DAE64FD514097921 DBA0C5 ?sequence $=1$

(25) Manderbacka K, Muuri A, Keskimäki I, ym. Mitä tyydyttymätön palvelutarve kertoo terveyspalvelujen saatavuudesta? Sosiaalilääketieteellinen aikakauslehti 2012;49: 4-12. 
(26) Sheppard R, Deane F, Ciarrochi J. Unmet need for professional mental health care among adolescents with high psychological distress. Australian \& New Zealand Journal of Psychiatry 2018;52: 59-67. doi: $10.1177 / 0004867417707818$

(27) Tylee A, Haller DM, Graham T, ym. Youthfriendly primary-care services: how are we doing and what more needs to be done? Lancet 2007;369: 1565-1573. doi: 10.1016/S0140-6736(07)60371-7

(28) Kanste O, Halme N, Perälä M-L. Viidesluokkalaisten oppilaiden näkemyksiä hyvinvoinnista, kouluyhteisöstä ja palveluista, Helsinki. Juvenes Print-Suomen Yliopistopaino Oy. 2017, 36.

(29) Peltola M, Moisio J. 2017. Ääniä ja äänettömyyttä palvelukentillä. Katsaus lasten ja nuorten palvelukokemuksia koskevaan tietoon. Nuorisotutkimusverkosto/Nuorisotutkimusseura. Verkkojulkaisuja 112. STM, Helsinki. Luettu 5.1.2018. http://www.nuorisotutkimusseura. fi/images/julkaisuja/aania_ja_aanettomyytta_ palvelukentilla.pdf

(30) Kanste O, Sainio P, Halme, N, ym. 2017. Toimintarajoitteisten nuorten hyvinvointi ja avun saaminen- Toteutuuko yhdenvertaisuus? Kouluterveyskyselyn tuloksia. Tutkimuksesta tiiviisti 24, elokuu 2017. THL. Helsinki. https://www.julkari.fi/bitstream/ handle/10024/135231/URN ISBN_978-952-302-838-8.pdf?sequence=1

(31) Marshall, E. Do Young Adults Have Unmet Healthcare Needs? Journal of Adolescent Health 2011;49: 490-497. doi: 10.1016/j.jadohealth.2011.03.005

(32) Hargreaves DS, Elliott MN, Viner RM, Richmond TK, ym. Unmet Health Care Need in US Adolescents and Adult Health Outcomes. Pediatrics 2015;136: 513-520. doi: 10.1542/peds.2015-0237

(33) Sawyer, S-M, McCarthy M, Orme L, ym. D. Unmet need for healthcare services in adolescents and young adults with cancer and their parent carers. Support Care Cancer 2017;25: 2229-2239. doi: 10.1007/s00520-017-3630-y

(34) Fjaer EL, Stornes P, Borisova LV, ym. Subjective perceptions on unmet need for health care in Europé among social groups: Findings from the European social survey (2014) special module on the social determinants of health. Eur J Public Health 2017;27: 82-89.

doi: 10.1093/eurpub/ckw219

(35) Terveyden ja hyvinvoinnin laitos 3. 2017. Kouluterveyskysely. Luettu 30.1.2019. https:// thl.fi/fi/tutkimus-ja-kehittaminen/tutkimukset-jahankkeet/kouluterveyskysely

(36) Terveyden ja hyvinvoinnin laitos 5. 2019. Kyselyn toteuttaminen. Luettu 19.5.2019. https://thl.fi/fi/tutkimus-ja-kehittaminen/ tutkimukset-ja-hankkeet/kouluterveyskysely/ kyselyn-toteuttaminen

(37) TENK. 2012. Hyvä tieteellinen käytäntö. Luettu 15.4.2019.

https://www.tenk.fi/fi/hyva-tieteellinen-kaytanto
(38) Terveyden ja hyvinvoinnin laitos 6. 2017. Kyselylomakkeet. Luettu 19.2.2019. https:// thl.fi/fi/tutkimus-ja-kehittaminen/tutkimuksetja-hankkeet/kouluterveyskysely/kyselyntoteuttaminen/kyselylomakkeet

(39) Terveyden ja hyvinvoinnin laitos 2. 2017. Kouluterveyskyselyyn vastaajat 2017 . Luettu 17.1.2019.

https://thl.fi/fi/web/lapset-nuoret-ja-perheet/ tutkimustuloksia/kaikki-kouluterveyskyselyntulokset/vastaajat

(40) Matikka A, Luopa P, Kivimäki H, ym. 2015. The well - being of eight - year and ninth - year pupils with an immigrant background -School Health Promotion Study 2013. Luettu 21.2.2019. http://www.julkari.fi/bitstream/ handle/10024/125546/ URN_ISBN_978-952-302-434-2. pdf? sequence $=1$ \&isAllowed $=y$

(41) Patio 1. 2015. Opiskeluhuollon saavutettavuus. Millainen on nuorten mielenterveys ja miten he käyttävät opiskeluhuoltopalveluja ja kokevat niiden saavutettavuuden? Luettu 20.2.2019. https://www.patio.fi/web/pepa-2015valtakunnallinen/opiskeluhuollon-saatavuus

(42) Koponen P, Kuusio H, Keskimäki I, ym. Unmet needs for medical care among migrants in Finland. European Journal of Public Health 2014;24: 118-119. doi:10.1093/eurpub/cku162.020

(43) Luopa P, Kivimäki H, Matikka A, ym. 2014. Nuorten hyvinvointi Suomessa 2000-2013.

Kouluterveyskyselyn tulokset. Luettu 19.2.2019. http://www.julkari.fi/bitstream/ handle/10024/116692/ URN_ISBN_978-952-302-280-5. pdf? sequence $=1 \&$ is Allowed $=y$

(44) Heikkilä T. Tilastollinen tutkimus, 7.-8. painos, Helsinki. Edita Prima Oy. 2010, 30.

\section{LAURA VäLKKILÄ}

TtM

Tampereen yliopisto

Yhteiskuntatieteiden tiedekunta, terveystieteet

KATJA JORONEN

$T t T$, dosentti

Tampereen yliopisto

Yhteiskuntatieteiden tiedekunta, terveystieteet

Anna-Maija Koivisto

FM, yliopisto-opettaja

Tampereen yliopisto

Yhteiskuntatieteiden tiedekunta, terveystieteet

Outi Kanste

$T t T$, dosentti

Oulun yliopisto

Hoitotieteen ja terveyshallintotieteen tutkimusyksikkö 